\title{
Perbedaan Pengetahuan dan Sikap Remaja Sebelum dan Sesudah Promosi kesehatan Tentang Dampak Rokok
}

\author{
Sulastri ${ }^{1}$, Rindu² \\ 1Puskesmas Anggadita Jl. Raya Desa Anggadita Klari Karawang Jawa Barat \\ 2Program Studi Ilmu kesehatan Masyarakat, Sekolah Tinggi Ilmu Kesehatan Indonesia Maju \\ JIn. Harapan Nomor 50, Lenteng Agung-Jakarta Selatan 1260, Telp : (021) 78894045 \\ Email : ${ }^{1}$ lastrigunawan69@gmail.com; ${ }^{2}$ rindualghie@gmail.com
}

\begin{abstract}
Abstrak
Rokok merupakan penyebab kematian utama di dunia dan merupakan satu-satunya produk legal yang membunuh hingga setengah penggunanya.Banyak faktor siswa untuk merokok salah satu yang mempengaruhi kebiasaan tersebut adalah pengetahuan dan sikap terhadap bahaya rokok itu sendiri. Pengetahuan dan sikap dapat dirubah dengan memberikan intervensi promosi kesehatan berupa penyuluhan kesehatan. Tujuan penelitian ini untuk mengetahui perbedaan pengetahuan dan sikap remaja sebelum dan sesudah promosi kesehatan tentang dampak rokok pada anak sekolah di SMPN I Klari Kabupaten Karawang. Penelitian ini menggunakan disain praeksperimen dengan rancangan One Group Pretest Posttest. Populasi yang diteliti adalah siswa kelas VII sebanyak 210 siswa. Sampel yang diambil berjumlah 138 siswa sesuai krtiteria inklusi. Tehnik pengambilan sampel dilakukan dengan tehnik Accidental Sampling. Hasil penelitian menunjukan bahwa pengetahuan siswa sebelum diberikan intervensi promosi kesehatan memiliki rata-rata nilai $18,40 \%$ sesudah diberikan intervensi promosi kesehatan 18,87\%. Sikap siswa sebelum diberikan intervensi promosi kesehatan memiliki rata-rata nilai $43,80 \%$ sesudah diberikan intervensi promosi kesehatan $46,43 \%$. Hasil uji Paired -sample T test dengan tingkat signifikan $(\alpha=0,005)$ di dapatkan pvalue $=0,000$ disimpulkan terdapat perbedaan pengetahuan dan sikap remaja sebelum dan sesudah promosi kesehatan tentang dampak rokok pada anak sekolah di SMPN I Klari Kabupaten Karawang. Bagi pihak sekolah diharapkan memberikan pengetahuan tentang dampak rokok sedini mungkin,dan siswa diharapkan tidak terjerumus dalam aktifitas yang merugikan. Pihak puskesmas diharapkan untuk giat dalam memberikan penyuluhan kesehatan tentang dampak rokok.
\end{abstract}

Kata kunci : Pengetahuan, Promosi Kesehatan, Sikap

\begin{abstract}
Cigarette is main death cause in world and is the only legal product killing is finite semi its the consumer. Many student factors to smoke one other influencing habit of is knowledge and position to danger of itself cigarette. convertible Knowledge and position by giving intervention of health promotion in the form of health counselling. Purpose of this research to know adolescent knowledge difference and position before and after health promotion about cigarette impact. This research applies designing praeksperimen with planning One Group Pretest Posttest. Population that is accurate is class student VII 210 students. Sample taken amounts to 138 students according to krtiteria inklusi.Technics of sampling is done technicsly Accidental Sampling.Result of research of that knowledge of student before given intervention of health promotion to have average of value $18,40 \%$ after given intervention of health promotion 18,87\%.position of Student before given intervention of health promotion to have average of value $43,80 \%$ after given intervention of health promotion $46,43 \%$.Test Result Paired - test tee sample with level of signifikan $(a=0,005)$ in getting value $=0,000$ concluded there is adolescent knowledge difference and position before and after health promotion about cigarette impact at schoolchild in SMPN I Klari Kabupaten Karawang.For the school is expected to gives knowledge about cigarette impact early mungkin,dan student is expected not to fall to in harming activity.The side of puskesmas expected for impetous in giving health counselling about cigarette impact.
\end{abstract}

Keywords : Attitude, Health Promotion, Knowledge 


\section{Pendahuluan}

Bahaya merokok terhadap kesehatan tubuh telah dirasakan banyak orang dan efek-efek yang ditimbulkan pun sudah diketahui dengan jelas. Banyak penelitian membuktikan kebiasaan merokok menyebabkan timbulnya berbagai penyakit dalam tubuh, seperti penyakit jantung dan gangguan pembuluh darah, kanker paruparu, kanker rongga mulut, kanker laring, tekanan darah tinggi, impotensi serta gangguan kehamilan dan cacat janin. Bahaya rokok juga bukan hanya ditunjukan bagi para perokok (perokok aktif) tetapi juga bagi orang-orang yang bukan perokok menghirup asap rokok yang berada disekitar perokok (perokok pasif) dan justru efek yang diterima dari perokok pasif akan jauh lebih berbahaya dari perokok aktif. $^{1}$

Hasil Riset menunjukan terjadinya peningkatan prevalensi perokok usia 15 tahun keatas yaitu 36,3\%. ${ }^{2}$ Walaupun proporsi perokok wanita lebih rendah dibandingkan pria, tetapi terjadi juga peningkatan sebanyak 5 kali lipat dari 1,7\% ditahun 1999 menjadi 6,7\% di tahun 2013. Prevalensi perokok di Indonesia sebesar 34,8\% dan sebanyak 67\% laki-laki di Indonesia adalah perokok. ${ }^{3}$ Dan lebih memprihatinkan lagi adalah kebiasaan buruk merokok juga meningkat pada generasi muda. Perilaku merokok pada remaja (perokok pemula) mengalami peningkatan dengan rincian sebagai berikut: Prevalensi perokok usia 10-14 tahun pada tahun 1995 sebanyak 8,9\% dan pada tahun 2013 mengalami peningkatan menjadi $18 \%$. Jumlah perokok laki-laki pada tahun 1995 sebanyak $27 \%$ dan meningkat di tahun 2013 menjadi 36,3\%. Perokok perempuan walaupun jumlahnya lebih sedikit dibandingkan dengan perokok laki-laki, juga mengalami peningkatan ditahun 1995 berjumlah 4,2\% menjadi $6,7 \%$ ditahun 2013. Demikian halnya dengan prevalensi perokok usia 16-19 tahun juga mengalami peningkatan dari 7,1\% di tahun 1995 menjadi 20,5\% di tahun $2014 .^{4}$
Provinsi Jawa Barat adalah provinsi kedua dengan jumlah perokok terbanyak di Indonesia. Proporsi penduduk usia di atas 10 tahun yang merokok setiap hari sebanyak 27,1\% di provinsi Jawa Barat. Sebanyak $50 \%$ usia mulai merokok terdapat pada usia 15-19 tahun di provinsi Jawa Barat. ${ }^{2}$

Indonesia menempati posisi tertinggi di dunia untuk angka perokok tertinggi di kalangan remaja. Sebagian besar laki-laki pertama kali merokok pada usia 12-13 tahun, sedangkan sebagian besar perempuan pertama kali merokok pada usia kurang dari 7 tahun dan 14-15 tahun, dan prevalensi tertinggi pengguna tembakau ada di usia 13-15 tahun (kelas VII-IX setingkat SMP/MTs). Hasil survey tersebut menunjukan bahwa sebanyak tiga dari lima pelajar terpapar asap rokok di rumah dan di tempat umum, $60 \%$ pelajar terpapar secara langsung oleh iklan rokok di berbagai media dan hampir $10 \%$ pelajar terekspos iklan rokok secara tidak langsung di Indonesia, sebanyak 20,3\% remaja menggunakan produk tembakau, $19,4 \%$ diantaranya perokok dan $2,1 \%$ menggunakan produk selain rokok. ${ }^{4}$

Akibat rokok di Indonesia menyebabkan 9,8\% kematian karena penyakit paru kronik dan emfisema pada tahun 2001. Rokok merupakan penyebab dari sekitar 5\% kasus stroke. Wanita yang merokok mungkin mengalami penurunan atau penundaan kemampuan hamil. Pada pria meningkatkan resiko impotensi sebesar $50 \%$. Ibu hamil yang merokok selama masa kehamilan atau terpapar asap rokok di rumahnya atau di lingkungannya beresiko mengalami proses kelahiran yang bermasalah, termasuk berat bayi lahir rendah, lahir mati dan cacat lahir. Lebih dari 40,3 juta anak Indonesia berusia 0-4 tahun tinggal dengan perokok dan terpapar asap rokok di lingkungannya, anak yang terpapar asap rokok di lingkungannya mengalami pertumbuhan paru yang lambat dan lebih mudah terkena infeksi saluran pernafasan, infeksi telinga dan asma. ${ }^{5}$ 
Perilaku merokok merupakan perilaku yang berbahaya bagi kesehatan, tetapi masih banyak orang yang melakukannya, bahkan orang mulai merokok ketika dia masih remaja. Perilaku merokok adalah perilaku yang dinilai sangat merugikan dilihat dari berbagai sudut pandang baik bagi diri sendiri maupun orang lain disekitarnya. ${ }^{6}$ Salah satu penyebab mengapa perokok baru terus bertambah adalah karena gencarnya iklan rokok yang beredar di masyarakat, ditambah dengan adanya image yang dibentuk oleh iklan rokok tersebut sehingga terlihat seakan orang yang merokok adalah orang yang sukses dan tangguh yang dapat melalui rintangan apapun. Iklan, promosi ataupun sponsor kegiatan yang dilakukan oleh para produsen rokok merupakan sarana yang sangat ampuh untuk mempengaruhi remaja dan anak-anak. Merokok mengakibatkan penurunan kesehatan yang berdampak pada penurunan kualitas anak-anak, generasi yang baru dilahirkan. Penurunan kualitas generasi penerus bangsa berakibat terjadinya pembodohan dan pemiskinan yang berkelanjutan dari generasi ke generasi sepanjang sejarah. ${ }^{7}$

Tingginya jumlah perokok di kalangan remaja sangat mengkhawatirkan, karena kurangnya pengetahuan siswa tentang rokok. Banyak faktor yang mendorong siswa untuk merokok, salah satu yang mempengaruhi kebiasaan tersebut adalah pengetahuan dan sikap terhadap bahaya rokok itu sendiri. Pengetahuan dan sikap ini dapat dirubah dengan penyuluhan dan bimbingan kesehatan. $^{8}$ Menurut Green pengetahuan dan sikap tersebut merupakan faktor presdisposisi dan perilaku seseorang. ${ }^{9}$

Promosi kesehatan secara umum adalah segala upaya yang direncanakan untuk mempengaruhi orang lain, baik individu, kelompok, atau masyarakat, sehingga mereka melakukan apa yang diharapkan oleh pelaku promosi kesehatan. Tujuan utama dari promosi kesehatan adalah perubahan perilaku. ${ }^{9}$
Meskipun tidak didapatkan data yang pasti tentang jumlah perokok di Kabupaten karawang, namun tingginya jumlah perokok di kalangan remaja dan masih kurangnya pengetahuan siswa tentang rokok, serta salah satu faktor yang mendorong siswa untuk merokok adalah pengetahuan dan sikap terhadap bahaya rokok itu sendiri, membuat peneliti ingin melakukan penelitian tentang "Perbedaan pengetahuan dan sikap remaja sebelum dan sesudah promosi kesehatan tentang dampak rokok pada anak sekolah di SMP Negeri 1 Klari kabupaten Karawang tahun 2017".

Tujuan Penelitian ini adalah mengetahui perbedaan pengetahuan dan sikap remaja sebelum dan sesudah promosi kesehatan tentang dampak rokok pada anak sekolah di SMP Negeri 1 Klari Kabupaten Karawang Tahun 2017.

\section{Metode}

Penelitian ini menggunakan disain penelitian studi intervensi dengan sifat preeksperimental dengan rancangan one group pretest and posttest design. Penelitian ini hanya menggunakan satu kelompok studi yang diberi intervensi (tanpa kelompok kontrol).

Penelitian dilakukan di SMPN 1

Klari Kabupaten Karawang. Populasi dalam penelitian ini adalah seluruh siswa kelas VII di SMPN 1 Klari pada tahun 2017 sebesar 210 siswa. Pengambilan sampel dilakukan dengan tehnik Accidental Sampling. Sampel yang dipilih memiliki kriteria Inklusi sebagai berikut: (1) siswa kelas VII laki-laki dan perempuan (2) bersedia menjadi responden (3) hadir pada saat penelitian berlangsung. Jumlah sampel yang diperlukan adalah sebesar 138 responden yang terdiri dari murid kelas VII di SMPN 1 Klari. Data yang diambil adalah data primer, merupakan data yang diperoleh dari responden melalui kuesioner. ${ }^{10}$ Data yang akan diperoleh menggunakan kuesioner yang di dalamnya terdiri beberapa 
pertanyaan yang berhubungan dengan variabel penelitian.

Instrumen penelitian ini menggunakan kuesioner pretest dan posttest. Sebelum digunakan dalam penelitian kuesioner terlebih dahulu dilakukan uji validitas dan reliabilitas. Reliabilitas adalah indeks yang menunjukan sejauh mana suatu alat pengukur dapat dipercaya. Hal ini sejauh mana hasil pengukuran tersebut tetap konsisten atau sama bila dilakukan pengukuran dua kali atau lebih terhadap gejala yang sama dengan menggunakan alat ukur yang sama. ${ }^{11}$ Uji validitas dan reliabilitas diolah menggunakan SPSS Statistic 17.

Variabel yang akan dianalisis menggunakan analisis univariat adalah pengetahuan dan sikap sebelum promosi kesehatan pada kelompok intervensi serta pengetahuan dan sikap setelah promosi kesehatan pada kelompok intervensi. Analisis bivariat merupakan analisis untuk melihat hubungan antara variabel dependen dan independen.

Uji yang digunakan pada penelitian ini, untuk melihat ada perbedaan pengetahuan dan sikap sebelum dan sesudah promosi kesehatan pada kelompok intervensi maka menggunakan uji T. Uji T yang digunakan dalam analisis bivariat dalam penelitian ini adalah uji beda dua mean dependen (uji T dependen).

Asumsi yang dipakai adalah apabilasignifikansi $\mathrm{t}$ lebih besar dari tingkat alpha $(\alpha)$ yang ditetapkan, maka variabel dependent tersebut tidak berpengaruh terhadap variabel dependen atau hipotesis yang diajukan tidak di dukung oleh data. Tetapi sebaliknya apabila nilai signifikansi t lebih kecil dari tingkat alpha yang digunakan maka data mendukung hipotesis penelitian. Bila $P_{\text {value }}$ $\leq$ 0,05 maka Ho ditolak, maka dapat disimpulkan ada perbedaan pengetahuan dan sikap remaja sebelum dan sesudah promosi kesehatan tentang dampak rokok di SMPN 1 Klari Tahun 2017. Namun sebaliknya bila $P_{\text {value }} \geq 0,05$ maka Ho gagal ditolak, dan disimpulkan tidak ada perbedaan pengetahuan dan sikap remaja sebelum dan sesudah promosi kesehatan tentang dampak rokok di SMPN 1 Klari Tahun 2017. Penelitian ini akan menggunakan level of significance $(\alpha)=$ $5 \%$, hal ini didasarkan pada penelitianpenelitian sebelumnya yang sejenis.

Hasil

Karakteristik responden dalam kuesioner Penelitian meliputi usia, jenis kelamin, serta status perokok. Untuk karakteristik usia, peneliti membagi usia responden dengan usia dibawah 13 tahun, usia 13 tahun, dan usia diatas 13 tahun. Sedangkan untuk status perokok responden peneliti membedakan berdasarkan perokok aktif, perokok pasif dan bukan perokok. Untuk lebih jelasnya dapat dilihat pada tabel berikut :

Tabel 1. Distribusi Frekuensi Variabel yang Diteliti

\begin{tabular}{llll}
\hline Variabel & Kategori & n & \% \\
\hline Umur & $<$ 13th & 34 & 24,6 \\
& 13th & 95 & 68,8 \\
\multirow{4}{*}{ Jenis Kelamin } & $>$ 13th & 9 & 6,5 \\
& Laki-Laki & 93 & 67,4 \\
& Perempuan & 45 & 32,6 \\
& Aktif & 1 & 0,7 \\
& Pasif & 9 & 6,5 \\
& Bukan & 128 & 92,8 \\
& perokok & & \\
\hline
\end{tabular}

Berdasarkan tabel 1, dapat diketahui bahwa mayoritas siswa kelas VII yang menjadi responden berusia 13 tahun berjumlah 95 responden dengan persentase $68,8 \%$. Responden yang berjenis kelamin laki-laki berjumlah 93 responden dengan persentase $67,4 \%$, dan jenis kelamin perempuan berjumlah 45 responden dengan persentase 32,6\%. Dan mayoritas responden berstatus bukan perokok sebanyak 128 responden dengan persentase $92,8 \%$.

Dari hasil Kuesioner dengan skala penilaian 10 sampai 20 dapat diketahui bahwa responden yang memiliki nilai ratarata skor pengetahuan sebelum diberikan intervensi promosi kesehatan adalah 18,40 yang mendapatkan skore terendah 15 
Tabel 2. Gambaran Pengetahuan dan Sikap Remaja Sebelum dan Sesudah diberi Intervensi Promosi Kesehatan Tentang Dampak Rokok

\begin{tabular}{ccccc}
\hline Pre test & Mean & SD & Min & Max \\
\hline Pengetahuan & 18,40 & 1,156 & 15 & 20 \\
Sikap & 43,80 & 4,200 & 32 & 50 \\
\hline Post test & & & & \\
\hline Pengetahuan & 18,87 & 1,113 & 16 & 20 \\
Sikap & 46,43 & 3,160 & 35 & 50 \\
\hline
\end{tabular}

Tabel 3. PerbedaanPengetahuandan Sikap RemajaSebelumDan Sesudah Promosi Kesehatan Tentang Dampak Rokok Pada anak Sekolah Di SMPN 1 Klari Kabupaten Karawang Tahun 2017

\begin{tabular}{ccccc}
\hline Pengetahuan & Mean & SD & P value & N \\
\hline Pre test & 18,40 & 1,156 & \multirow{2}{*}{0,000} & \multirow{2}{*}{138} \\
Post test & 18,87 & 1,113 & & \multirow{2}{*}{138} \\
\hline Sikap & & & \multirow{2}{*}{0,000} & \multirow{2}{*}{ Pre test } \\
Post test & 43,80 & 4,200 & 3,160 & \\
\hline
\end{tabular}

sebanyak 1 orang $(0,7 \%)$ dari hasil kuesioner dan skor tertinggi 20 sebanyak 22 orang $(15,9 \%)$.

Sedangkan hasil kuesioner dengan skala penilaian 10 sampai 50 dapat diketahui nilai rata-rata skor sikap responden sebelum diberikan intervensi promosi kesehatan adalah 43,80 yang mendapatkan skor terendah 32 sebanyak 1 orang $(0,7 \%)$ dari hasil kuesioner dan skor tertinggi 50 sebanyak 6 orang $(4,3 \%)$.

Dari tabel.2 dapat diketahui nilai rata-rata skor pengetahuan responden sesudah diberikan intervensi promosi kesehatan adalah 18,87 yang mendapatkan skor terendah 16 sebanyak 4 orang $(2,9 \%)$ dari hasil kuesioner dan skor tertinggi 20 sebanyak 49 orang $(35,5 \%)$. Dan diketahui nilai rata-rata skor sikap responden setelah diberikan intervensi promosi kesehatan adalah 46,43 yang mendapatkan skore terendah 35 sebanyak 1 orang $(0,7 \%)$ dari hasil kuesioner dan skor tertinggi 50 sebanyak 29 orang $(21,00 \%)$.

Dari Tabel 3, diketahui bahwa ratarata skor pengetahuan sebelum dilakukan intervensi promosi kesehatan adalah 18,40 dengan standar deviasi 1,156. Sedangkan rata-rata skore pengetahuan sesudah dilakukan intervensi promosi kesehatan adalah 18,87dengan standar deviasi 1,113. Dari hasil uji statistik diperoleh nilai probabilitas (Pvalue) sebesar,000 artinya pada alpha $5 \%$ terdapatperbedaan rata-rata skor pengetahuan sebelum dan sesudah diberikan intervensi promosi kesehatan tentang dampak rokok.

Dari hasil uji $\mathrm{T}$ dependen pada tabel 3 , diketahui bahwa rata-rata skor sikap sebelum dilakukan intervensi promosi kesehatan adalah 43,80 dengan standar deviasi 4,200 Sedangkan rata-rata skor sikap sesudah dilakukan intervensi promosi kesehatan adalah 46,43 dengan standar deviasi 3,160. Dari hasil uji statistik diperoleh nilai probabilitas (Pvalue) sebesar 0,000 artinya pada alpha $5 \%$ terdapat perbedaan rata-rata skor sikap sebelum dan sesudah diberikan intervensi promosi kesehatan tentang dampak rokok.

\section{Pembahasan}

\section{Pengetahuan Remaja Sebelum Promosi Kesehatan Tentang Dampak Rokok Pada Anak Sekolah Di SMPN 1 Klari Kabupaten Karawang}

Diketahui bahwa skor pengetahuan responden sebelum diberikan intervensi promosi kesehatan yang terendah adalah 15 sebanyak 1 orang $(0,7 \%)$ Sedangkan yang mendapat skor tertinggi 20 sebanyak 22 orang (15,9\%). Pengetahuan yang dimaksud dalam penelitian ini adalah pengetahuan sebelum 
intervensi promosi kesehatan tentang segala sesuatu yang berhubungan dengan rokok dan bahayanya yang meliputi : zat yang terkandung dalam rokok, perokok aktif dan perokok pasif, serta penyakitpenyakit yang ditimbulkan akibat rokok.

Pengetahuan adalah hasil penginderaan manusia, atau hasil tahu seseorang terhadap objek melalui indera yang dimilikinya (mata, hidung, telinga, dan sebagainya). Dengan sendirinya pada waktu penginderaan sampai menghasilkan pengetahuan tersebut sangat dipengaruhi intensitas perhatian dan persepsi terhadap objek. Sebagian besar pengetahuan seseorang diperoleh melalui indera pendengaran (telinga), dan indera penglihatan (mata). ${ }^{12}$

Menurut hasil penelitian Hanifah di SMPN 2 Kartasura menyebutkan sebelum dilakukan penyuluhan gizi dengan menggunakan media video sebagian sampel memiliki tingkat pengetahuan yang tidak baik, sebesar $66,7 \%$. Hal tersebut karena sebelumnya sampel belum pernah mendapatkan penyuluhan kesehatan tentang pengetahuan gizi seimbang. Informasi tentang gizi seimbang hanya diperoleh dari buku dan penjelasan dari para pengajar. ${ }^{13}$

Penelitian Rohmawati, dkk menyebutkan kategori pengetahuan sebelum dilakukan penyuluhan yaitu sebanyak 15 orang $(48,4 \%)$ mempunyai pengetahuan kurang dan hanya 3 orang $(9,7 \%)$ yang mempunyai pengetahuan baik, ketidak tahuan wanita usia subur tentang kontrasepsi implan dipengaruhi oleh kurangnya informasi serta sebagian besar berpendidikan sekolah dasar. ${ }^{14}$

Hasil penelitian Marhaeni dkk, menyebutkan sebelum diberikan intervensi penyuluhan kesehatan tentang HIV-AIDS pengetahuan remaja masih dalam kategori kurang yaitu dengan median 56, rentang 48-64. Hal tersebut terjadi karena kegiatan KSPAN di SMA 1 Sidemen kurang mendapat perhatian dan jarang melakukan kegiatan. Hal ini menyebabkan siswa hanya memperoleh informasi dari media sosial dan teman maupun keluarga yang belum tentu kebenarannya. ${ }^{15}$

Berdasarkan hasil kuesioner penelitian dengan skala penilaian 10 sampai 20 bahwa rata-rata pengetahuan responden sebelum diberikan intervensi promosi kesehatan mendapatkan skor rendah yaitu 18,40 . Skor yang rendah ini didapatkan karena mayoritas responden belum mengetahui tentang segala sesuatu yang berhubungan dengan rokok dan bahayanya yang meliputi : zat yang terkandung dalam rokok, perokok aktif dan perokok pasif, serta penyakit-penyakit yang ditimbulkan akibat rokok. Serta kurangnya informasi yang diterima responden tentang dampak rokok.

\section{Pengetahuan Remaja Sesudah Promosi Kesehatan Tentang Dampak Rokok Pada Anak Sekolah Di SMPN 1 Klari Kabupaten Karawang}

Berdasarkan hasil penelitian dapat diketahui bahwa setelah diberikan intervensi promosi kesehatan responden yang memiliki skor nilai rata-rata pengetahuan terendah 16 sebanyak 4 orang $(2,9 \%)$ Sedangkan yang mendapat skor tertinggi 20 sebanyak 49 orang (35,5\%). Menurut Kamus Besar Bahasa Indonesia (KBBI) Pengetahuan berarti segala sesuatu yang diketahui, kepandaian atau segala sesuatu yang diketahui dengan hal (mata pelajaran). Penginderaan terjadi melaui panca indera manusia, yaitu indera penglihatan, penciuman, rasa dan raba. Sebagian besar pengetahuan merupakan domain yang sangat penting untuk terbentuknya tindakan seseorang (over behavior). Menurut Ikhsan peningkatan pengetahuan dan pemahaman responden tentang bahaya merokok dapat terjadi akibat proses pemberian edukasi yakni pendidikan kesehatan. ${ }^{16}$

Hasil penelitian Nuradita dalam Rusmilawati menyimpulkan bahwa ada pengaruh pendidikan kesehatan terhadap pengetahuan tentang bahaya rokok pada remaja di SMPN 3 kendal. Tumigolong dalam Rusmilawati menyimpulkan bahwa 
pendidikan kesehatan berpengaruh pada pengetahuan siswa tentang bahaya merokok. ${ }^{17} \quad$ Rohmawati, dkk menyimpulkan bahwa responden mengalami peningkatan pengetahuan setelah dilakukan penyuluhan. ${ }^{14}$

Berdasarkan hasil kuesioner penelitian dengan skala penilaian 10 sampai 20 bahwarata-rata pengetahuan responden setelah diberikan intervensi promosi kesehatan mendapatkan skor 18,87 .

Pengetahuan setelah dilakukannya intervensi terlihat lebih tinggi dibandingkan pengetahuan sebelum intervensi, Pengetahuan yang dimaksud dalam hal ini adalah pengetahuan setelah intervensi promosi kesehatan tentang segala sesuatu yang berhubungan dengan rokok dan bahayanya yang meliputi : kandungan zat utama dalam rokok, bahaya kesehatan yang ditimbulkan oleh rokok, perbedaan perokok pasif dan perokok aktif serta akibat rokok pada organ tubuh. faktor yang mempengaruhi pengetahuan salah satunya adalah informasi, dan informasi dalam hal ini adalah promosi kesehatan.

\section{Sikap Remaja Sebelum Promosi Kesehatan Tentang Dampak Rokok Pada Anak Sekolah di SMPN 1 Klari Kabupaten Karawang}

Berdasarkan hasil penelitian diketahui bahwa sebelum diberikan intervensi promosi kesehatan responden yang memiliki skor nilai rata-rata sikap terendah 32 sebanyak 1 orang $(0,7 \%)$ Sedangkan yang mendapat skor tertinggi 50 sebanyak 6 orang $(4,3 \%)$. Sikap adalah respon tertutup seseorang terhadap stimulus atau objek tertentu, yang sudah melibatkan faktor pendapat dan emosi yang bersangkutan (senang-tidak senang, setuju-tidak setuju, baik-tidak baik, dan sebagainya). Campbell mendefinisikan sikap itu suatu sindrom atau kumpulan gejala dalam merespons stimulus atau objek, sehingga sikap itu melibatkan pikiran, perasaan, perhatian, dan gejala kejiwaan yang lain. ${ }^{12}$
Hasil penelitian Rusmilawati mendapatkan hasil sikap perokok aktif sebelum diberikan penyuluhan tentang bahaya rokok ada pada kategori negatif yaitu sebanyak $56,4 \%$ dan memiliki skor 23 sampai dengan $24 .^{17}$

Hasil penelitian Zayanti, dkk menyebutkan bahwa sikap remaja sebelum mendapatkan promosi kesehatan sebagian besar memiliki sikap positif $(55,1 \%)$ dan yang memiliki sikap negatif $(44,9 \%)$ hal ini menunjukan ketidak setujuan remaja terhadap seks bebas dilihat dari sikap positif remaja lebih besar dibandingkan dengan sikap negatifnya. ${ }^{18}$

Berdasarkan hasil kuesioner penelitian dengan skala penilaian 10 sampai 50 diketahui bahwarata-rata sikap responden sebelum diberikan intervensi promosi kesehatan mendapatkan skor rendah yaitu 43,80. Sikap yang dimaksud dalam penelitian ini adalah sikap sebelum intervensi promosi kesehatan tentang pernyataan-pernyataan yang diberikan kepada responden yang bersifat negatif dan positif terhadap rokok dan dampak yang ditimbulkannya. Salah satu faktor yang mempengaruhi pembentukan sikap adalah pengetahuan. Diketahui bahwa rata-rata pengetahuan responden sebelum diberikan intervensi promosi kesehatan mendapatkan skor rendah, kurangnya informasi yang diterima responden mengenai rokok dan dampaknya berpengaruh terhadap rendahnya sikap responden terhadap bahaya rokok.

\section{Sikap Remaja Sesudah Promosi Kesehatan Tentang Dampak Rokok Pada Anak Sekolah di SMPN 1 Klari Kabupaten Karawang}

Diketahui bahwa setelah diberikan intervensi promosi kesehatan responden yang memiliki skor nilai rata-rata sikap terendah 35 sebanyak 1 orang $(0,7 \%)$ Sedangkan yang mendapat skor tertinggi 50 sebanyak 29 orang $(21 \%)$. Newcomb mengatakan bahwa sikap merupakan kesiapan atau kesediaan untuk bertindak, dan bukan merupakan motif tertentu. ${ }^{10}$ 
Dalam kata lain, fungsi sikap belum merupakan tindakan (reaksi terbuka) atau aktifitas, akan tetapi merupakan predisposisi perilaku (tindakan) atau reaksi. Sikap (attitude) merupakan "reaksi atau respon yang masih tertutup dari seseorang terhadap suatu stimulus atau objek" ?

Penelitian yang dilakukan oleh Saskia menunjukan bahwa terdapat pengaruh yang signifikan pemberian penyuluhan terhadap sikap siswa tentang bahaya merokok. ${ }^{19}$ Promosi kesehatan yang telah diberikan sebelumnya mampu menambah pengetahuan dan persepsi remaja tentang merokok, akibatnya sikap remajapun akan menjadi lebih baik dibandingkan dengan sikap remaja sebelum dilakukan promosi kesehatan. ${ }^{20}$ Marhaeni, dkk dalam penelitiannya menyimpulkan remaja sudah mulai menunjukan sikap positif setelah diberikan penyuluhan. ${ }^{15}$ Hal ini sesuai dengan hasil yang di dapat oleh Ayuningsih bahwa penyuluhan berpengaruh terhadap pengetahuan dn sikap siswa tentang HIVAIDS. ${ }^{15}$

Rata-rata sikap responden setelah diberikan intervensi promosi kesehatan adalah 46,43. Sikap setelah dilakukannya intervensi terlihat lebih tinggi dibandingkan sikap sebelum intervensi, sikap yang dimaksud dalam hal ini adalah sikap setelah intervensi promosi kesehatan tentang pernyataan-pernyataan yang diberikan kepada responden yang bersifat negatif dan positif terhadap rokok dan dampak yang ditimbulkannya. Salah satu komponen yang membentuk sikap diantaranya adalah keyakinan atau kepercayaan terhadap obyek. Setelah mendapatkan informasi tentang rokok dan dampaknya dalam tubuh, maka responden memiliki pendapat atau keyakinannya terhadap dampak rokok.

\begin{tabular}{|c|c|}
\hline Per & getahuan \\
\hline & Sesudah \\
\hline
\end{tabular}

\section{Pada Anak Sekolah di SMPN 1 Klari Kabupaten Karawang}

Diketahui hasil penelitian bahwa rata-rata skor pengetahuan responden sebelum dilakukan intervensi promosi kesehatan adalah 18,40 sedangkan hasil skor rata-rata pengetahuan sesudah dilakukan intervensi promosi kesehatan adalah 18,87. Dari hasil analisis statistik Paired-samples T-test diperoleh nilai probabilitas (Pvalue) sebesar 0,000. Hal ini berarti pada derajat kepercayaan $95 \%$ $(\alpha=0,05)$ nilai $P_{\text {value }}<0,05$ maka dapat disimpulkan ada perbedaan pengetahuan remaja sebelum dan sesudah promosi kesehatan tentang dampak rokok pada anak sekolah di SMPN 1 klari Kabupaten Karawang.

Pengetahuan adalah hasil penginderaan manusia, atau hasil tahu seseorang terhadap objek melalui indera yang dimilikinya (mata, hidung, telinga, dan sebagainya). Dengan sendirinya pada waktu penginderaan sampai menghasilkan pengetahuan tersebut sangat dipengaruhi intensitas perhatian dan persepsi terhadap objek. Sebagian besar pengetahuan seseorang diperoleh melalui indera pendengaran (telinga), dan indera penglihatan (mata). ${ }^{12}$

Perubahan perilaku kesehatan melalui cara pendidikan atau penyuluhan kesehatan diawali dengan cara pemberian informasi-informasi kesehatan. ${ }^{9}$ Dengan memberikan informasi-informasi tentang cara-cara mencapai hidup sehat, cara pemeliharaan kesehatan, cara menghindari penyakit, dan sebagainya akan meningkatkan pengetahuan masyarakat tentang hal tersebut. Selanjutnya dengan pengetahuan-pengetahuan itu akan menimbulkan kesadaran mereka, dan akhirnya akan menyebabkan orang berperilaku sesuai dengan pengetahuan yang dimilikinya. ${ }^{17}$

Hasil penelitian Ambarwati, dkk yang sejalan dengan penelitian Salaudeen menyimpulkan bahwa pendidikan kesehatan secara statistik berpengaruh pada peningkatan pengetahuan siswa 
tentang masalah yang berkaitan dengan kebiasaan merokok. ${ }^{8}$

Berdasarkan hasil penelitian

Puryantodalam Ikhsandiketahui bahwa ada pengaruh yang signifikan antara sebelum dan sesudah pemberian pendidikan kesehatan terhadap pengetahuan dan sikap siswa tentang bahaya merokok. ${ }^{16}$ Penelitian Tumigolongdalam Rusmilawati membuktikan bahwa pendidikan kesehatan berpengaruh terhadap tingkat pengetahuan siswa tentang bahaya merokok di SMAN 1 Manado. ${ }^{17}$

Faktor-faktor yang mempengaruhi pengetahuan salah satunya adalah informasi. $^{12}$ Yang dimaksud dengan informasi dalam penelitian ini adalah Promosi kesehatan. Pemberian promosi kesehatan berpengaruh terhadap peningkatan pengetahuan seseorang. Salah satu kegiatan promosi kesehatan adalah pemberian informasi atau pesan kesehatan untuk memberikan atau meningkatkan pengetahuan dan sikap tentang kesehatan agar memudahkan terjadinya perilaku sehat. ${ }^{16}$

Tingkatan pengetahuan seseorang terhadap objek berawal dari tahu (know) yang diartikan sebagai reccall (memanggil) memori yang telah ada sebelumnya setelah mengamati sesuatu, memahami (comprehension) artinya dapat menginterpretasikan secara benar tentang objek yang diketahui tersebut, aplikasi (application) yang artinya dapat menggunakan prinsip yang diketahui pada situasi yang lain, analisis (analysis) yaitu kemampuan seseorang untuk menjabarkan atau memisahkan kemudian mencari hubungan antara komponen-komponen yang terdapat dalam suatu masalah atau objek yang diketahui, sintesis (synthesis) maksudnya menunjukan kemampuan seseorang untuk merangkum atau meletakan dalam satu hubungan yang logis dari komponen-komponen pengetahuan yang dimiliki, evaluasi (evaluation) berkaitan dengan kemampuan seseorang untuk melakukan justifikasi atau penilaian terhadap sesuatu obyek tertentu. ${ }^{12}$
Sebelum mendapat promosi kesehatan pengetahuan remaja sebatas tahu dan setelah mendapat intervensi promosi kesehatan menjadi memahami karena jawaban benar lebih banyak. Hal ini sesuai dengan pernyataan bahwa tingkat pengetahuan seseorang diawali dari tahu (know) yang diartikan sebagai mengingat suatu materi yang telah dipelajari sebelumnya dalam hal ini responden tahu tentang definisi rokok, zat utama yang ada dalam rokok, racun-racun yang dapat ditemukan dalam rokok, apa yang disebut dengan perokok aktif dan perokok pasif, akibat yang ditimbulkan dari rokok terhadap kesehatan serta bagaimana terjadinya penyakit akibat racun-racun yang ada dalam rokok seperti apa yang disampaikan dalam promosi kesehatan, kemudian memahami (comprehension) yang dalam hal ini responden dapat menjelaskan mengapa zat-zat racun yang ada dalam rokok dapat menyebabkan berbagai macam gangguan dalam tubuh, setelah mengetahui dan memahami dampak rokok tehadap kesehatan responden tersebut dapat mengaplikasikannya dalam situasi yang lain, dalam hal ini menerapkannya pada dirinya sendiri, selanjutnya responden dapat menganalisis hubungan antara rokok dengan kejadian penyakit yang ditimbulkannya dan mereka dapat menyimpulkan apa yang dapat terjadi jika mereka menjadi perokok serta mereka dapat menilai apakah mereka menjadi perokok aktif, perokok pasif atau bukan perokok.

Selain itu alat bantu yang digunakan untuk melakukan promosi kesehatan dapat mendukung proses dalam penyampaian materi sehingga dapat meningkatkan pengetahuan remaja. Dalam penelitian ini alat bantu yang penulis gunakan dalam promosi kesehatan adalah slide materi, video dan presentasi materi. Promosi kesehatan dengan materi dampak rokok mampu mempengaruhi pengetahuan karena peneliti menampilkan gambargambar yang berhubungan dengan bahaya 
rokok dalam tubuh manusia baik perokok aktif maupun perokok pasif, gambargambar zat utama dalam rokok serta racunracun yang terdapat dalam zat utama rokok, serta pemutaran video bagaimana rokok dapat menyebabkan berbagai macam penyakit dalam tubuh sehingga materi dianggap menarik. Semakin banyak indera yang digunakan untuk menerima informasi maka semakin jelas pula pengertian atau pengetahuan yang diperoleh.

Setelah diberikan promosi kesehatan mengenai dampak rokok pengetahuan remaja di SMPN 1 Klari Kabupaten karawang memiliki skore rata-rata nilai 18,87 . Hasil penelitian ini sejalan dengan hasil penelitian Zayanti, dkk yang menyatakan bahwa pengetahuan remaja di desa Cilayung setelah diberikan promosi kesehatan menjadi meningkat. ${ }^{18}$

\section{Perbedaan Sikap Remaja Sebelum Dan Sesudah Promosi Kesehatan Tentang Dampak Rokok Pada Anak Sekolah di SMPN 1 Klari Kabupaten Karawang}

Diketahui hasil penelitian bahwa rata-rata skor sikap responden sebelum dilakukan intervensi promosi kesehatan adalah 43,80 sedangkan hasil skor rata-rata sikap sesudah dilakukan intervensi promosi kesehatan adalah 46,43. Dari hasil analisis statistik Paired-samples T-test diperoleh nilai probabilitas (Pvalue) sebesar 0,000 . Hal ini berarti pada derajat kepercayaan 95\% $(\alpha=0,05)$ nilai Pvalue $<$ 0,05 maka dapat disimpulkan ada perbedaan sikap remaja sebelum dan sesudah promosi kesehatan tentang dampak rokok pada anak sekolah di SMPN 1 klari Kabupaten Karawang.

Sikap (attitude) merupakan "reaksi atau respon yang masih tertutup dari seseorang terhadap suatu stimulus atau objek" 9. Sikap merupakan reaksi atau respon yang masih tertutup terhadap suatu stimulus atau obyek. Manifestasi sikap tidak dapat dilihat, tetapi hanya dapat ditaksirkan. Sikap merupakan kecenderungan yang berasal dari dalam diri individu untuk berkelakuan dengan pola-pola tertentu, terhadap suatu obyek akibat pendirian dan perasaan terhadap obyek tersebut. ${ }^{19}$

Sikap adalah suatu bentuk evaluasi atau reaksi perasaan. Sikap seseorang terhadap suatu obyek adalah perasaan mendukung atau memihak (favorable) maupun perasaan tidak mendukung atau tidak memihak (unfaforable) pada obyek tersebut. ${ }^{19}$ Perubahan sikap tergantung dari cara atau metode yang digunakan dalam menyampaikan pesan atau program. Pada prinsipnya semakin banyak panca indera yang digunakan untuk menerima sesuatu maka semakin banyak dan jelas pula pengertian atau pengetahuan yang diperoleh. ${ }^{9}$

Dalam menentukan sikap yang utuh, pengetahuan, pikiran, keyakinan, dan emosi memegang peranan yang sangat penting sehingga manusia dapat menerima, menanggapi, menghargai dan bertanggung jawab terhadap apa yang telah diyakininya. ${ }^{12}$

Penyuluhan kesehatan dapat mempengaruhi sikap seseorang, dimulai dari menambah pengetahuan dan wawasan perokok aktif tentang bahaya rokok. ${ }^{17}$ Berdasarkan hasil penelitian Saskia menunjukan bahwa terdapat pengaruh yang signifikan pemberian penyuluhan terhadap sikap siswa tentang bahaya rokok. Penelitian lain menyebutkan bahwa ada pengaruh penyuluhan dengan metode ceramah tentang bahaya rokok terhadap perubahan sikap perokok aktif di Desa Tirtajaya kecamatan Bajuin Kabupaten Tanah Laut Tahun 2014. ${ }^{19}$

Sikap mempunyai tingkat-tingkat berdasarkan intensitasnya, yaitu menerima (receiving) yang diartikan bahwa seseorang atau subyek mau menerima stimulus yang diberikan (obyek), menanggapi (responding) artinya memberikan jawaban atau tanggapan terhadap pertanyaan atau obyek yang dihadapi, menghargai (valuing) yaitu subyek atau seseorang memberikan nilai yang positif terhadap obyek atau stimulus, serta bertanggung jawab (responsible) 
merupakan tingkatan sikap yang paling tinggi dimana bila seseorang yang telah mengambil sikap tertentu berdasarkan keyakinannya, dia harus berani mengambil resiko bila ada orang lain yang mencemooh atau adanya resiko lain. ${ }^{9}$

Berdasarkan hasil kuesioner penelitian tentang sikap sebelum mendapatkan promosi kesehatan sikap remaja terhadap dampak rokok memiliki skor rata-rata 43,80 sedangkan hasil skor rata-rata sikap sesudah dilakukan intervensi promosi kesehatan adalah 46,43. Seperti telah dijelaskan diatas bahwa pemberian promosi kesehatan berpengaruh terhadap peningkatan pengetahuan seseorang. Salah satu kegiatan promosi kesehatan adalah pemberian informasi atau pesan kesehatan untuk memberikan atau meningkatkan pengetahuan dan sikap tentang kesehatan agar memudahkan terjadinya perilaku sehat. Perbedaan nilai ini dapat diartikan bahwa sikap remaja setelah mendapatkan promosi kesehatan tentang dampak rokok telah sampai pada tingkat menerima yang diartikan bahwa remaja mau dan menerima stimulus yang diberikan, dalam hal ini responden mau hadir untuk mengikuti penyuluhan tentang dampak rokok, kemudian merespon yaitu memberikan jawaban ketika ditanya setelah dilakukan promosi kesehatan, selanjutnya menghargai dalam arti mengerjakan dan menyelesaikan tugas yang diberikan dalam hal ini kuesioner posttest, dan memberikan jawaban sesuai apa yang diyakininya terkait dengan pengetahuan yang telah didapatkan setelah promosi kesehatan .

Tujuan promosi kesehatan berupa penyuluhan kesehatan yaitu meningkatkan kesadaran, meningkatkan pengetahuan, mempengaruhi sikap dan persepsi untuk berperilaku, memperagakan ketrampilan sederhana, memotivasi tindakan serta membangun norma. ${ }^{19}$ Setelah diberikan promosi kesehatan mengenai dampak rokok sikap remaja di SMPN 1 Klari Kabupaten Karawang memiliki skore ratarata 46,43 , hasil penelitian ini sejalan dengan penelitian yang menyatakan bahwa sebelum diberikan promosi kesehatan sikap remaja di desa Cilayung mempunyai kategori sikap positif sebesar $55,1 \%$ dan setelah diberikan promosi kesehatan meningkat menjadi $71,0 \% .^{18}$

\section{Kesimpulan}

Dari penelitian ini dapat disimpulkan bahwa terdapat perbedaan pengetahuan dan sikap remaja sebelum dan sesudah promosi kesehatan tentang dampak rokok. Promosi kesehatan berupa penyuluhan, mempunyai pengaruh dalam upaya meningkatkan pengetahuan dan sikap remaja untuk memelihara dan meningkatkan kesehatan khususnya tentang dampak rokok. Mayoritas remaja kelas VII yang berada di SMP Negeri 1 Klari Kabupaten Karawang adalah bukan perokok.

Kepada sekolah membuat kebijakan dengan memberikan sanksi tegas bagi seluruh siswa sekolah yang merokok di sekolah, serta menjadikan sekolah sebagai kawasanTanparokok (KTR) dan Siswa sedini mungkin perlu diberi pengetahuan tentang bahaya merokok bagi kesehatan dan penanaman arti penting perilaku hidup sehat. Dengan bertambahnya pengetahuan siswa SMP tentang bahaya merokok diharapkan akan merubah perilaku siswa SMP untuk tidak merokok dan siswa tidak terjerumus dalam aktivitas yang merugikan kesehatan seperti merokok, karena dapat mengakibatkan generasi muda kita akan memiliki kualitas kesehatan yang buruk dan akan berpengaruh pada produktivitas kerja. Serta bagi peneliti selanjutnya untuk melakukan penelitian lanjutan mengenai pengaruh promosi kesehatan terhadap peningkatan pengetahuan dan sikap remaja terhadap dampak rokok, untuk melakukan pengukuran pengetahuan dan sikap dengan jeda waktu selama satu minggu serta melakukan penelitian lanjutan tentang tehnik promosi kesehatan dalam rangka peningkatan pengetahuan dan sikap remaja terhadap dampak rokok. 


\section{Daftar Pustaka}

1. Hartono GF. Bahaya merokok bagi kesehatan. Semarang: Fakultas Ilmu Pendidikan Universitas Negeri Semarang; 2013.

2. Kemenkes RI. Hasil Riskesdas 2013. http://depkes.go.id/downloads/riskesdas2013/ha sil\%20Riskesdas\%202013.pdf. Diakses tanggal 15 mei 2017.

3. Kemenkes RI. Balitbangkes. Riset Kesehatan Dasar.

2013http://depkes.go.id/downloads/riskesdas20 13/hasil\%20Riskesdas\%202013.pdf.Diaksestan ggal 15 mei 2017.

4. Aditama TY et al. GlobalYouth Tobacco menghubungkan survey (GYTS) data ke WHO konvensi kerangka kerja pengendalian tembakau:kasus untuk Indonesia,2008. http://www.ncbi.nlm.nih.gov/pubmed/18585772 . Diakses tanggal 12 mei 2017.

5. Kementrian Kesehatan RI, Pedoman pengembangan kawasan tanpa rokok: Pusat promosi kesehatan, Jakarta, 2011.

6. Aulia LE, Stop merokok. Yogyakarta: Gara Ilmu; 2010.

7. Kementrian Kesehatan RI. Wujudkan generasi muda Indonesia bebas tembakau 2015. possore.com/.../menkes-wujudkan-generasimuda-Indonesia-bebas-tembakau. Diakses 15 mei 2017.

8. Ambarwaty dkk. Jurnal kesehatan Masyarakat. Vol.10/ Januari 2014. Media leaflet,video dan

17. Rusmilawaty. Pengaruh penyuluhan metode ceramah tentang bahaya rokok terhadap perubahan sikap perokok aktif.Banjarmasin: Jurnal Vokasi Kesehatan, volume II nomor 2/ Juli 2016 hlm 317-322; 2016.

18. Zayanti N, dkk. Perbedaan pengetahuan dan sikap remaja sebelum dan sesudah diberikan promosi kesehatan mengenai bahaya seks bebas di desa Cilayung; 2015. pengetahuan siswa SD tentang bahaya merokok. Universitas Muhammadiyah: Surakarta.2013.

9. Notoatmodjo S. Promosi kesehatan dan perilaku kesehatan. Jakarta: Rineka Cipta; 2012.

10. Sujarweni V W. Metodologi penelitian keperawatan. Yogyakarta: Gava Medika; 2014.

11. Notoatmodjo S. Metodologi penelitian kesehatan. Jakarta: Rineka Cipta; 2012.

12. Notoatmodjo S. Promosi kesehatan teori \& Aplikasi. Jakarta: Rineka Cipta; 2010.

13. Hanifah DL. Perbedaan pengetahuan remaja sebelum dan sesudah diberikan penyuluhan gizi seimbang dengan menggunakan media video di SMPN 2 Kartasura. Surakarta: Universitas Muhammadiyah Surakarta; 2014.

14. Rohmawaty E, Suprapti, Damayanti FN. Perbedaan pengetahuan sebelum dan sesudah penyuluhan tentang kontrasepsi implan. Semarang: Universitas Muhammadiyah Semarang; 2011.

15. Marhaeni GA, Hadi MC, Armini NW. Intervensi penyuluhan kesehatan terhadap peningkatan pengetahuan dan sikap remaja tentang HIV-AIDS di SMA 1 Sidemen Kabupaten Karangasem Provisi Bali. Bali: Poltekes Kemenkes Denpasar; 2013.

16. Ikhsan H, Arwani, Purnomo. Pengaruh pendidikan kesehatan bahaya merokok terhadap perilaku mengurangi konsumsi rokok pada remaja. Semarang: STIKES Telogorejo Semarang; 2013.

19. Saskia RR. Penyuluhan tentang bahaya merokok terhadap sikap siswa kelas VI di SDN Gedog Wetan Turen Kabupaten Malang: Malang; 2015.

20. Fitrianingrum L. Pengaruh promosi kesehatan terhadap sikap remaja tentang merokok di SMP Muhammadiyah 1 Minggir Sleman Yogyakarta: Yogyakarta; 2012. 